\title{
The implementation of Guessing aGme technique in teaching speaking
}

\author{
Anggun Dwi Cahyani', Ag. Bambang Setiyadi' ${ }^{2}$ Mahpul $^{3}$ \\ Universitas Lampung, Jl. Prof. Dr. SumantriBrojonegoro, Rajabasa, Bandarlampung ${ }^{1,2,3}$ \\ ${ }^{1}$ Correspondence: anggundwichyn@gmail.com
}

\begin{abstract}
Capability of speaking in English has necessarily become the need of the students of senior high school. However, the majority of the students have low capability of speaking. This was due to a number of factors, one which was the inappropriate use of the method the teacher used in the classroom. The guessing game technique was beloved to have enabled students to improve their speaking capability.

The current research aimed to investigate i) the significant improvement of the students' speaking ability after the implementation of the guessing game technique, ii) the effect of the guessing game technique on the students' capability in every single aspect of speaking and, iii) the correlation between the students' attitudes and their speaking achievement.

The subjects of the research were 35 students at SMAN 1 Sidomulyo. There were three raters who assessed students' speaking ability. The data were collected trough the tests (pre-test and post-test) and questionnaires. Furthermore, the Repeated measure t-test was used to analyze the data collected from both the pre and the post tests. While, the data from questionnaires were analyzed by using Pearson product moment.

The results showed that the guessing game technique has a statistically significant effect on the students' speaking ability with the significant level 0.05 . Moreover, there was correlation between the students' attitudes and their speaking achievement. This suggests that the guessing game technique facilitates students to improve their capability of speaking.
\end{abstract}

Keywords: speaking, guessing game technique, descriptive text, attitude

\section{INTRODUCTION}

Speaking is the way someone expresses his thought by formulating verbal utterance. By speaking, people can express their ideas, knowledge, or information and it belongs to productive skills (Nunan, 2003). In learning English, speaking becomes one of four skills that has to be well-mastered by the students (Brown, 2004). This indicates that speaking has an important role for the students in improving their ability to use English as a foreign language.

In curriculum 2013, the students are expected to be able to speak English, but in reality, many students including the first-grade students of X MIA 1 in SMAN 1 Sidomulyo, who have spent many years studying English, are still not able to speak English fluently. This indicates that speaking is the most difficult skill for students to learn. There are some reasons why students find it difficult to speak English. One of the reasons is thatthey are lazy to practice speaking English because they had lack of vocabulary mastery and confidence.

Referring to problem above, this research is also supported by some previous research, the first one is conducted by Fitriana. She found some problems affecting students' speaking performance in the class such as lack of vocabulary and motivation to speak English, and then, the other research which has been conducted byFairuz, Fitriani, and Burhansyah showed that junior high school students of SMPN 2 Lhokseumawe had some problems to speak English because they rarely practice. So, a good technique of teaching English especially speaking skill is important to make students more active and confident. 
One of the techniques in teaching speaking is by using games. By using games, teachers can create a good situation for students to learn English in the classroom. Moreover, after applying game the students will feel more eager to learn and not scare to practice. Besides that, Lee (1990) claims that games are enjoyable.

In line with the previous research, Puspitasari (2018)believes that games can keep students' motivation. It means games can encourage students' motivation. Evidently, games not only fun and interesting, but it can be used to motivate the students to practice speaking English. According to Klippe 1(1994) the basic rule of guessing game is prominently simple; one person knows something than another one has to find out what it is. It can be summarized that someone knows something, and the others must find out what is the object that describes by the speaker. This is also admitted by Mora \&Lopera (2001) who state that the guessing game is more than just having fun, stress that game and fun activities have been one of every body's favorite things to do in class, both for teachers and students since games can develop series of skills and competencies, the game can be implemented in the class.

The previous study which conducted by Fitriana (2012), she says that the teacher must selective in choosing games which can improve students' speaking skill, the game should be interactive and interesting for the students. She claimed that the implementation of the guessing game technique is effective to teach seventh Grade Students of SMP Muhammadiyah. Here, the writer believes that the Guessing Game Technique will make speaking activity becomes joyful and attractive.

Furthermore, to know about the students' attitude is also essential, Brown (2007) states that attitude as a set of beliefs that a learner holds toward the target language whether it is important, interesting, boring, and so forth. From that, the researcher knows whether the technique is good or not for the students. Besides that, the students who have a positive attitude towards learning, it can improve their learning achievement (Veloo, Nor, \& Khalid 2015).

Considering the findings of the previous studies the researcher conducted a research about "The Implementation of Guessing Game Technique in Teaching Speaking". This research tries to investigate the significant improvement of the students' speaking ability after the implementation of the guessing game technique, to find out the effect of the guessing game technique on the students' achievement of every single aspect of speaking and to identify the correlation between the students' attitudes and their speaking achievement.

\section{METHODS}

\section{Participants}

The participants of this research were 35 first grade students at SMAN 1 Sidomulyo (Class X MIA 1).

\section{Instruments}

In the current study the researcher collected the data by using instruments namely, speaking test and questionnaire. The first instrument was speaking test, it used for pretest and posttest. Besides that, the researcher also spreading the questionnaire in order to know about the 
correlation between students' attitudes and their speaking achievement. The questionnaire was adapted from Setiyadi (2018).

\section{Data Analysis}

This research was conducted through quantitative approaches. Then, the design of this research was the one group pretest-posttest with the formula (T1 X T2). Furthermore, to find out the statistically significant improvement of students' speaking ability after the students' were taught through the guessing game technique, the data were analyzed by using Paired Sample t-test. While, The Pearson Product Moment was used to analyze the correlation between students' attitudes and their speaking achievement.

\section{RESULTS AND DISCUSSIONS}

\section{Results}

After analyzing the data, the researcher gained the improvement of the students' score of pretest and posttest. The statistical calculation was presented in table1, respectively as shown below.

Table 1. Descriptive statistic of pre-test and post-test

\begin{tabular}{llllll}
\hline & $\mathrm{N}$ & Minimum & Maximum & Mean & Std. Deviation \\
\hline Pre-test & 35 & 54.00 & 70.70 & 60.4914 & 4.89630 \\
Post-test & 35 & 68.70 & 90.30 & 80.1829 & 6.23135 \\
& & & & & \\
Valid N & 35 & & & & \\
& & & & & \\
\hline
\end{tabular}

Table 1 shows that there was an improvement between students' mean score of pre-test and post-test from $60.49 \mathrm{u} p$ to 80.18 after the implementation of guessing game technique, with the lowest score of pre-test was 54.00 and the lowest score of post-test was 68.70 . While, to know the statistically significant improvement, Paired sample T-test was used to the data. The result can be seen in the table below:

Table 2.The Hypothesis of Paired Samples T-Test

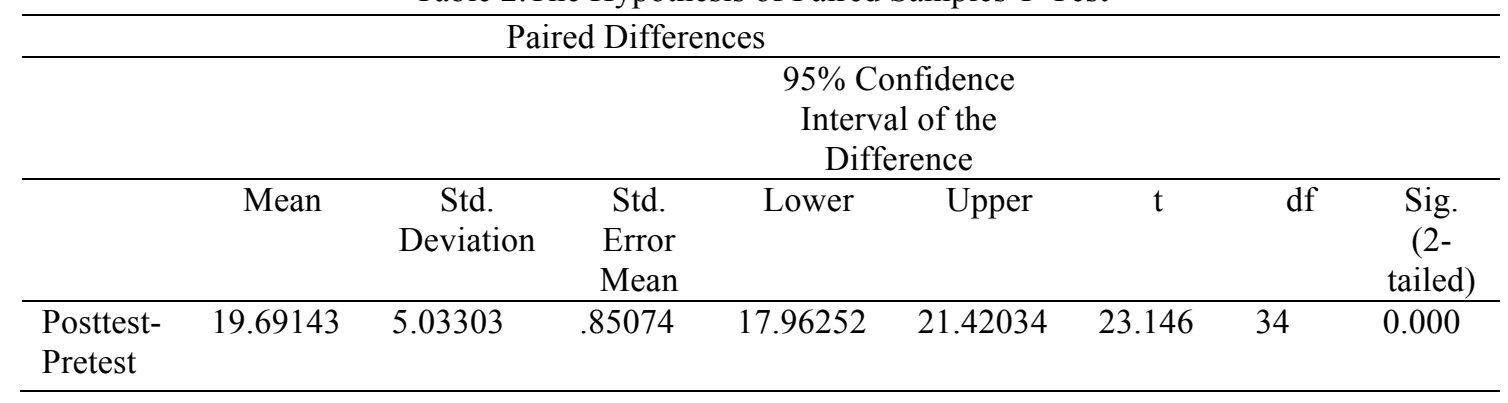

The current study, which involves 35 students of class X science 1 of SMAN 1 Sidomulyo, provides evidence that the significance score was lower than 0.05.It shows that the significance score was 0.000 . Then, the score of T-value was 23.146 and t-table was 2.045 , it means T-value was higher than T-table. Hinge on this result, there was statistically significant improvement of the students' speaking ability after the implementation of the guessing game technique. 
Furthermore, to answer the second research question about the effect of the guessing game technique on the students' achievement of every single aspect of speaking will be presented in the table 3-4:

Table 3.The Improvement of Every Single Aspect of Speaking

\begin{tabular}{llccc}
\hline No. & \multicolumn{1}{c}{ Aspect of Speaking } & Pre-test & Post-test & Improvement \\
\hline 1. & Pronunciation & 11,9 & 15,6 & 3,7 \\
2. & Vocabulary & 12,3 & 16,4 & 4,1 \\
3. & Fluency & 11,9 & 15,9 & 4 \\
4. & Comprehension & 12,6 & 16,8 & 4,2 \\
5. & Grammar & 11,8 & 15,5 & 3,7 \\
\hline & Total & 60,5 & 80,2 & 19,7 \\
\hline
\end{tabular}

As shown in table3there was an improvement in each aspect of speaking after the implementation of the guessing game technique for three times of the treatments. It can be seen from the total score of the test increased from 60,5 in the pre-test to 80,2 in the post-test. Here, in the pre-test the students still got low scores in each aspect of speaking, grammar was the lowest aspect with the average score 11,8 , one of the reasons why they got low scores because the researcher found a lot of grammatical errors. Besides that. there was pronunciation and fluency, they often pronounced the word incorrectly and some of them still got confused because they did not know how to pronounce the words in the right way, it made them got stuck so that they can not speak fluently. Furthermore, it followed by vocabulary and comprehension. From this data we can see the improvement of each aspect of speaking, there were the highest and lowest score but, pronunciation and grammar have the same score so that the researcher tried to find out $\mathrm{N}$ gain score of each aspect, so here is the table.

Table 4. N Gain Score of Every Single Aspect of Speaking

\begin{tabular}{clc}
\hline No. & \multicolumn{1}{c}{ Aspect of Speaking } & Mean of N Gain Score \\
\hline 1. & Pronunciation & 45.8923 \\
2. & Vocabulary & 53.1599 \\
3. & Fluency & 49.7201 \\
4. & Comprehension & 56.8912 \\
5. & Grammar & 46.1338 \\
\hline
\end{tabular}

As shown in table 4. It could be seen that comprehension was the aspect of speaking that improved the most with the mean of $\mathrm{N}$ gain score 56.8912 , followed by vocabulary which has score 53.1599, then fluency, pronunciation, and grammar. Furthermore, the significance score of each aspect will be described as follows.

Table 5. The Significance of Every Single Aspect of Speaking

\begin{tabular}{llllll}
\hline $\begin{array}{l}\text { Aspect of } \\
\text { speaking }\end{array}$ & $\begin{array}{l}\text { Mean (Pre- } \\
\text { test) }\end{array}$ & $\begin{array}{l}\text { Mean (Post- } \\
\text { test) }\end{array}$ & $\begin{array}{l}\text { Score } \\
\text { Improvement }\end{array}$ & T-Value & Sig. (2 tailed) \\
\hline Pronunciation & 11.9 & 15.6 & 3.68571 & 21.533 & 0.000 \\
Vocabulary & 12.3 & 16.4 & 4.05429 & 18.347 & 0.000 \\
Fluency & 11.9 & 15.9 & 3.97714 & 19.000 & 0.000 \\
Comprehension & 12.6 & 16.8 & 4.21429 & 23.290 & 0.000 \\
Grammar & 11.8 & 15.5 & 3.76571 & 16.022 & 0.000 \\
\hline
\end{tabular}


The table above shows that all aspects of speaking tests were significant because the score of significant (2-tailed) in all aspects lower than 0.05 .

Moreover to answer the third research question which is the correlation between students' attitudes and their speaking achievement will be described in the following table:

Table 6.Correlation betweenthe Students' Attitudesand Their Speaking Achievement

\begin{tabular}{llcc}
\hline & & Attitude & Speaking Achievement \\
\hline Attitude & Pearson Correlation & 1 & $.424^{*}$ \\
& Sig. (2-tailed) & & .011 \\
& N & 35 & 35 \\
Speaking & Pearson Correlation & $.424^{*}$ & 1 \\
Achievement & Sig. (2-tailed) & .011 & \\
& N & 35 & 35 \\
\hline
\end{tabular}

*. Correlation is significant at the level 0.05level (2-tailed).

As shown in table 6there was positive a relation with the score 0.424 ,it means there was an average correlation between the students' attitudes with their speaking achievement. Furthermore, there was a significance level with the score $0.011<0.05$ it means p lower than 0.05 (Setiyadi, 2018 ). Hinge on the result the researcher believed that students' attitudes could increase students' speaking ability.

\section{Discussions}

\section{The Statistically Significant Improvement of the Students' Speaking Achievement}

Owing to the result above, it approved that there was statistically significant improvement of students speaking ability since the significance was higher than $\alpha$. It indicates that the hypothesis propose was accepted. Moreover, it implies that the guessing gametechnique had positive effectson improving students' speaking ability and could make them felt confident.

This result supports the previous research finding which conducted byFairuz, Sarah, and Burhansyah (2018),they found that there was a difference in students speaking achievement after the implementation of the guessinggame and it has positive influences in students' speaking skill, especially in the field of vocabulary. This result also supported by Wright,Wright, Betteridge, and Buckby (1983) who state that game can be found to give practice in all skill (reading, speaking, listening, and speaking) in all stages on teaching-learning sequence. So, the researcher believed that the Guessing Game Technique could improve students' speaking ability,by guessing game, the students were able to learn all aspects of speaking easier since playing the guessing game was very interesting and challenging. According to Lee(1990) who says "guessing games can be applied at various age levels in general; the challenge to guess arouses considerable interest and encourages the learners to communicate". From his explanation, it sums up that guessing game is such a challenging game because the students are demanded to guess the object that has already described by their friends. 


\section{The Improvement of Speaking Aspect}

After implementing the guessing game technique, the result of all aspect were improve. Those aspects are :

\section{a. Pronunciation}

The pronunciation aspect was improved because the students could pronounce the words properly. At the pre-test, they said some words incorrectly such as the word "describe" they said "discrib" then, the word "here" they could say it "hir" and most of them said the words "was" and "is" by using "s". The other students got confused because some of them pronounced some words incorrectly. Then, after the implementation of guessing game technique, they knew how to pronounce those words correctly because during leaning process the researcher gave the audio about how to pronounce some words correctly.

\section{b. Vocabulary}

Referring to vocabulary, it was found out that there was an improvement in the vocabulary aspect. Vocabulary was the second aspect that improved the most after the implementation of the guessing game technique with the mean score in the pre-test was 12.3 and theme and score in the post-testwas 16.4. Thus, the improvement of this type was 4.10 with $\mathrm{N}$ gain score 53,1599 . It could improve because in every meeting the researcher gave them chances to make descriptive text and practice with their pairs.

\section{c. Fluency}

The guessing game technique also had a good impact on helping the students to speak English fluently. It was proved by the mean score of pre-test which was only 11.9 and the mean score in the post-test was 15.9. Thus, the improvement of this type was 4 with $\mathrm{N}$ gain score 49.7201 . It refers to the fact that the students were familiar with the words since they mostly find those words in the class of learning process. At the pre-test, many students got stuck and then made them stopped the explanation about describing people. It happened because of their habit, it was very seldom for them to speak English. Nevertheless, after the treatments there was an improvement of students' ability in the aspect of fluency.

\section{d. Comprehension}

Concerning to comprehension, it was found that there was an improvement in this aspect after the implementation of the guessing game technique. Rest on the data, comprehension is the aspect of speaking which improved the most with the highest increased score which is 4.2 with $\mathrm{N}$ gain score 56.8912. Specifically, the mean score of the pre-test was 12.6 and the mean score of the post-test was 16.8. Ultimately, the students' capability in terms of comprehension was increased after the treatments although, at the pre-test and first meeting they were still got confused when other students were described their favorite public figure, it was hard for them to guess. Meanwhile, in the post-test, the students were able to guess about the object that was described by their friends. It was easy for them to guess because they understood about the descriptive text that told by their friends. It can be concluded that the students had good comprehension. This supports the statement from Burns and Claire (2003) who state that when the listener understands the meaning from what the speaker said it called comprehensibility, it 
means when the listener can understand what the speaker said he/she has good comprehension. Since the students kept practice to speak English everyday, so they started to be familiar with the words it would help them in improving their speaking ability and comprehension.

\section{e. Grammar}

Referring to grammar, the guessing game had a good effect on students' improvement in the aspect of grammar. More specifically, it was found that the mean score of the pre-test was 11.8, and the mean score in the post-test was15.5. The improvement of this type was 3.7 with $\mathrm{N}$ gain score 46.1338 .

In this research, the aspect of speaking in pre-test and post-test were compared to determine the aspect that improved the most. So, comprehension was the aspect that improved the most and then followed by vocabulary, fluency, grammar, and pronunciation.

It can be summarized that, since the students could guess the object that had described by their friends it means they had good comprehension with the meaning of the text. This finding supports the theory from Harris (1969) who states that comprehension for oral communication certainly requires a subject to respond to speech as well as to initiate it.

\section{The Correlation Between the Students' Attitudes and Their Speaking Achievement}

The researcher was investigated the correlation between the students' attitudes with their speaking achievement by spreading the questionnaire, it was consisting of 15 questions. The questionnaire was adapted from Setiyadi (2018). Then, Pearson Product Moment in Bivariate Correlation(SPSS22.0forWindows) was used to test the hypothesis, in which the correlation was determined by $\mathrm{p}<0,05(\mathrm{p}=0,011)$. Stand on the data, the significant score was lower than 0.05 and then $r$ (correlation) was 0.424 . It means there was a positive correlation between the students' attitudes through students speaking achievement. This supports the statement from Setiyadi (2018) who states that there was an average correlation when $r$ value gained score ranging 0.400-0.600.In addition, $\mathrm{H}_{0}$ was rejected and $\mathrm{H}_{1}$ was accepted.

By spreading the questionnaire, the researcher knew that many students became more confident to speak English and performed in front of the class, they were very enjoying. This supports the statement of Brown (2007) who says that attitude as a set of beliefs that a learner holds toward the target language whether it is important, interesting, boring, and so forth. Then, other experts Veloo, Nor, and Khalid (2015) explain that the students who have a positive attitude towards learning, it can improve their learning achievement. It means students' attitudes could improve students speaking achievement. Furthermore, Setiyadi (2018) states that attitude evokes motivation, and motivation is the key to success in second language learning. It can be summarized that the students who had positive attitude would feel motivated to learn English. So, based on the finding of the study the researcher knew that the students who got a big score they had positive attitudes while, students who got low score had bad attitudes. Broadly says, it was found that most of students' in X MIA 1 had positive attitudes towards the technique, so that they could get better score in the pre-test. 


\section{CONCLUSIONS AND SUGGESTIONS}

\section{Conclusions}

The objectives of this research were to investigate whether the implementation of guessing game techniques can improve students' speaking skill or not, to find out the effect of the guessing game technique on the students' capability in every single aspect of speaking and to identify the correlation between the students' attitudes and their speaking achievement.

Owing to the result and discussion, it can be summarized that the implementation of guessing game technique was effective to improve students' speaking skill. It could be seen from the improvements of students' speaking mean score in the pre-test and post-test(60.49to80.18) and the significance value was lowest than 0.05 . So, it can be concluded that the implementation of guessing game technique was more helpful to improve students' capability of speaking. Besides that, the guessing game also could increase students' capability in every single aspect of speaking; there were comprehension, vocabulary, fluency, grammar, and pronunciation. Then, most of students had positive attitudes toward the technique. It can be seen from the score of $r$ (correlation) was 0.424 and the score ofp $<0.05(\mathrm{p}=0.011)$.

\section{Suggestions}

Considering to the conclusion above, the researcher would like to recommend some suggestions. Suggestions for English teachers, it is suggested to apply the guessing game technique in the class as an alternative way of teaching speaking. This is because the technique was very interesting and fun. It was able to increase students' speaking ability. Furthermore, English teachers are also suggested to manage the time properly when introducing the rules of the game; the teachers should explain the rules as clear as possible in order to avoid misunderstanding. Then, during the activity and when conducting the post-test, the teacher needs to be consistent with the time given for every section of the game and the test. Whereas, the suggestions for further researchers, this study was conducted in senior high school level. So that, further researchers can conduct the guessing game technique in different level of school. It can be implemented in elementary school or even in university. This study was used the questionnaires in order to know about students' attitudes and the researcher only took one class as the experimental class. Moreover, further researchers are suggested to develop the study by adding an interview and control class.

Briefly, those are the conclusion and suggestions of the findings for the English teacher and further researcher who want to implement the Guessing Game Technique to improve students' speaking ability.

\section{REFERENCES}

Brown H. D. (2004). Language assessment principle and classroom practices. New York, NY: Pearson Education.

Brown, H. D. (2007). Principles of language learning and teaching (5 $5^{\text {th }}$ ed.). New York, NY: Longman. 
Burns, A. \& Claire, S. (2003). Clearly speaking:pronunciation in action for Teachers. Digital or Visual products, Sydney: National Centre for English Language Teaching and Research (NCELTR), Macquarie University.

Fairuz,G., Fitriani,S.,\& Burhansyah.(2018).The use of guessing game in teaching speaking. Syiah Kuala University, Banda Aceh, Indonesia.

Fitriana, D. (2012). Improving the speaking skills through guessing games of the seventh grade students of SMPMuhammadiyah 1 Seyegan Yogyakarta in the academic year of 2012/2013.University of Yogyakarta, Yogyakarta, Indonesia.

Harris, D. P.(1969).Testing English as a secondlanguage. New York, NY: Mcgraw-Hill/.

Klippel,F.(1984).Keep talking: Communicative fluency activities for language teaching. Cambridge: Cambridge University Press.

Lee,W.R.(1994). Languageteaching game and contest $\left(2^{\text {nd }}\right.$ ed.).Toronto, New York: Oxford University Press.

Lubis A. (2014). An introduction to the 2013 curriculum. Retrieved from https://Www.Academia.Edu/18137460/An_Introduction_To_The_2013_Curriculum

Mora, R. A., \& Lopera,M.C.(2001). Games in classroom, more than just having fun.A Colombian journal for English Teachers. Bogota: University Colombia.

Nunan, D. (Ed.). (2003). Practical English language teaching ( $1^{\text {st }}$ ed.).Cambridge:Cambridge University Press.

Puspitasari, Z. (2018). Theeffect of using interactive guessing game technique on fluency student's speaking skill.University of Muhammadiyah Gresik, Gresik, Indonesia.

Setiyadi, A. B. (2018). Metode penelitian untuk pengajaran bahasa asing pendekatan kualitatif dan kuantitatif edisi 2. Yogyakarta: Grahallmu.

Veloo,A., Nor,R., \& Khalid, R. (2015). Attitude towards Physics and additional Mathematics achievement towards Physics achievement.Malaysian international journal of applied education studies,8(3), 35-43. Retrieved from http://dx.doi.org/10.5539/ies.v8n3p35

Wright, A.,Betteridge, D., Buckby, M. (2006). Games for language learning(3 $\left.{ }^{\mathrm{rd}} \mathrm{ed}.\right)$. Cambridge: Cambridge University Press. 